\title{
Knowledge Production, Community Engagement/Development and Global Climate Change
}

\author{
Kola O. Odeku \\ Edson L. Meyer \\ Institute of Technology, University of Fort Hare, Alice, South Africa \\ Email: kooacademics@gmail.com
}

\section{Doi:10.5901/mjss.2014.v5n7p671}

\begin{abstract}
A lot of research works have been conducted by scholars and researchers in the areas of global climate change showcasing meaningful and useful findings. However, when it comes to application of the results, very little has been done. Against the backdrop of the shortfall in disseminating and physical application of research findings to solve climate and environmental problems, this paper advocates for a linkage between research conducted and application of the result to solve the problems being encountered by the people. The paper explains that the only way to put the impact of climate change under control either by mitigation or adaptation is to ensure that research results are practicalised and applied to real life situations. This is informed by the fact that a lot of research works have been successfully conducted but the results are put on the shelves and continue to gather dust instead of being demonstrated. The article presents some useful examples of how the results of a few completed research works have been applied to meet the needs of communities and contributed immensely by improving the quality and standard of living of the people.
\end{abstract}

Keywords: Research, Findings, Implementation, Rural Community, Global Climate Change

\section{Introduction}

The core functions of most, if not all of the universities are teaching, learning, research and community engagement (Waghid, 2002). While research, teaching and learning usually take place in most time within the confine of the university environment, community engagement is usually done outside the university (Weerts and Sandmann, 2008). It requires taking new knowledge produced and physically demonstrating and applying to real life situation the findings of the research conducted to the community for the purposes of positively impacting the lives of the people in the community (Sanoff, 2000). Community engagement is described in the website of University of Fort Hare thus "in line with its vision and mission statements, community engagement at the University of Fort Hare refers to all negotiated and dynamic partnerships between the university and the community it serves, which is practiced through varied initiatives focused on the interlace of teaching and research, and aimed at addressing the social, cultural and economic development objectives of society."

A closer look at the description of community engagement above testifies to overall vision and mission of the University of Fort Hare to wit; partner, collaborate and engage with the community it serves. Pursuant to this, the university offers its skills and expertise to the community in the areas of contribution to the upliftment and improvement of the socio-economics standards of the community.

Since 1994, most of the tertiary institutions in South Africa have begun to rethink and restrategise their visions and missions toward implementation of community driven research and outreach. Several factors were responsible for this. Prior 1994, the apartheid government and its educational policies were mainly there to serve the narrow interest and agenda of the regimes (Cross et al, 2002). Hence, a lot of research works that were embarked on and carried out at the universities, mainly white dominated universities focused on how to sustain the apartheid regime (Muthayan, 2005). Historically Black Universities (HBUs) were however deprived of the opportunities to engage in any meaningful scientific and engineering related research activities (Livermore and Midgley, 1998). This is the reason why most of the HBUs are restricted to and labelled as teaching Universities as opposed to research Universities (Ilorah, 2006).

The situation has now changed with the advent of democratic dispensation and constitutional democracy. The South African constitution guarantees the right to education in the Bill of Rights. There is no limitation. Pursuant to this, Blacks and other races can venture into any discipline of their choice (Ackerman, 2004). 
Against the backdrop of the current educational landscape, virtually all universities in South Africa have now recognised the need to develop students' civic capacity and prepare them for active participation in implementation of useful projects in the communities (Netshandama, 2010). It is pertinent to mention that most of the HBU in South Africa are situated in the rural areas and as such have robust community engagement outreach (Fourie, 2006). An example is the University of Fort Hare, a HBU situated in Alice in the rural Eastern Cape. Consequent upon this, research works being conducted or already completed are proving invaluable to the surrounding communities at large and improving the standard of living of the otherwise impoverished rural people. The impacts of these research works have vast possibilities for mitigating and adapting to the impact of climate change by providing clean renewable energy for electricity which are being used to drive agri-business for food production, economic growth and wealth creation.

\section{Literature Review}

Contemporary educational policy now focuses more on the need for universities to integrate their teaching and research activities that will be of immense benefits to the communities (Epstein, 1996). This is the reason why in today's higher educational dispensation, the university is integrated into the community because the benefits are mutual to the university and the community ( Ibidunni, 2013). Reinforcing this observation, Bruning et al (2006) assert that "many colleges and universities recognize the benefits of being engaged in the community and have attempted to integrate the university into the community. Because the notion a seamless community and university has increased in popularity" ( Bruning et al, 2006).

Hall (2010:3), narrating the evolution and inclusion of community engagement in South Africa Educational system writes that "the appropriate starting point for considering South African Higher Education Policy is the White Paper of 1997, which informed the Higher Education Act of the same year." In essence, the 1997 White Paper sets out an agenda for the transformation of Higher Education from the segregated, inequitable and highly inefficient apartheid institutions, towards a single national system that serves both individual and collective needs (Maharajh, 2011). Along with teaching and research, community engagement is cast as one of the pillars of this system (Lange, 2012). Universities are called upon to "demonstrate social responsibility ... and their commitment to the common good by making available expertise and infrastructure for community service programmes." A key objective is to "promote and develop social responsibility and awareness amongst students of the role of higher education in social and economic development through community service programmes" (Hall, 2010).

With regard to transformation in the educational system that seeks to produce knowledge required to meet the newly acquired status of the democratic dispensation in South Africa, Waghid (2002:457) notes that "to be a university academic at the present time in post-apartheid South Africa should be both disturbing and challenging. Globally (South Africa inclusive) there is a shift towards problem-solving or applied as opposed to disciplinary research (ways of experiencing and constructing knowledge) as a result of a growing demand for social relevance and accountability.... In view of this emergent shift in knowledge production or formation (research), universities are increasingly being challenged in terms of their responsiveness and relevance to societal needs....Given the extent of world-wide moral, economic and social problems, there is increasing pressure on universities to bridge the gap between higher education and society and "to become active partners with parents, teachers, principals, community advocates, business leaders, community agencies, and general citizenry."

Explaining what community engagement connotes Hall (2010:7) asserts that "community engagement can be understood as a cluster of activities that includes service learning, problem-based teaching and research that addresses specific wants and needs, the pursuit of alternative forms of knowledge and challenges to established authorities that control and direct research systems and the allocation of qualifications (although this basket of concepts will need to be disaggregated later)."

Explaining the essence and significance of community development Hall (2010:27) puts it this way "what is understood and implied in the concept of community engagement can be understood as a part of a set of public goods emanating from higher education. This approach

allows the objectives of community engagement to be understood within their context without recourse to a generalised notion of doing good. For South Africa, responding to the imperatives of the public good would include addressing inequality measured in terms such as the Gini coefficient and household income, contributing to redressing inequities in the provision of education and housing, public health provision and countering HIVIAIDS, providing access to legal resources and similar priorities. This would be the appropriate regional version of the agora that Gibbons has written about and, from the point of view of the state, a logical way of measuring part of the return on the investment of public funds in higher education." 
The proposal written by Meyer in 2008 to Eskom to fund a project titled "Development of Excellence in Renewable Energy" outlined the objectives thus:

"Development of human and research capacity to support industry confronting the real threats caused by fossil fuels.

- Improvement of the quality of life for rural and urban communities, through innovation.

- Contribution to an increase in the number of black scientists in the generic society.

- Empowerment of students to help fulfil the need for renewable expertise in South Africa.

- Promote the continuous improvement of environmentally friendly technology through the demonstration of the commercial relevance and viability thereof.

- Community outreach through the installation of renewable energy systems at local schools, community centres and individual houses.

- Recognition as a Centre of Excellence by NRF and DST."

Above stated objectives indicate the objectives and significant of the research project and the components of the alliance together with the roles to be played during the course of the project up to its successful completion.

In 2008, the Council of the University of South Africa (UNISA) tacitly approved a community engagement and outreach policy for the University. The policy outlines how the University will engage with the community also by way of an outreach. The aim of the policy is derived from the vision of the university to connect with the Society and "utilise the resources and capacities of the University in community development initiatives and collaborative partnerships."(UNISA, 2008:3). This policy is remarkable because it encompass both community engagement and outreach. The Policy defines community engagement as "initiatives and processes through which the expertise of the institution in the areas of teaching and research are applied to address issues relevant to its community. Community engagement typically finds expression in a variety of forms, ranging from informal and relatively unstructured activities to formal and structured academic programmes addressed at particular community needs... and some projects might be conducive towards the creation of a better environment for community engagement and others might be directly related to teaching and research" (UNISA, 2008:3).

The policy also explains that "community engagement is a two-way relationship in which the University forms partnership with the community that yield beneficial outcomes such as productive research outcomes, human capital development and the development of cultural and intellectual assets for the community."

Community outreach is described as "the voluntary outreach to communities by academics, University employees, alumni or students in response to the social, economic and political needs of communities. This is a one-way initiative from the University, its students and alumni to communities."

The common characteristics in the definitions, descriptions and explanations of community engagement are the collaborative nature of its service to the society and humanity. This also covers community outreach.

The policy makes an elaborate explanation of the principles of community engagement and outreach. Pursuant to this and in order to fully appreciate the principles, the full text is provided thus."

And emphasise that "community engagement and outreach projects must be well planned in order to be effective. Transient incursions into communities could be disruptive or they could place a burden on the community or UNISA... The Directorate: Community Engagement and Outreach will focus on the management, coordination, facilitation, recognition and record keeping of community engagement and outreach programmes/projects... Community engagement is a core function of the University, together with teaching and research. Community engagement must promote the social, environmental, economic and cultural development of communities...

Community engagement must promote the mutually beneficial interaction between UNISA and communities. There should be collaboration on the development of academic programmes and research projects by all stakeholders... Community engagement is a scholarly activity that must enrich and contextualise the curriculum and research. "Engagement scholarship is the knowledge, discovery, integration, application, and teaching that results from universitycommunity collaborations... Collaboration and partnerships are the cornerstones of community engagement... Relationship building is a core principle in all community engagement initiatives. The University must develop relationships with local and regional authorities, governmental and non-governmental agencies, civic/community-based organisations and other UNISA communities...All community engagement projects must be needs-focused/driven... Student learning in community engagement academic programmes must be assessed, especially in terms of the link between theory and practice. Students' critical reflections on their experiences must inform curricula changes... After the completion of a research project that involves community engagement, the effectiveness of community engagement must be evaluated." 
However, with regard to the principles of community outreach, the policy indicates that "community outreach is not seen as a core function of the University" (UNISA 2008:8). This is peculiar to UNISA because community outreach need not necessarily be the core function of the University provided the outreach is making meaningful and useful contributions to the community. It will be regarded as something worth supporting and so that the people involved will not have the impression that they are doing something that is less meaningful (Eckert and Henschel, 2000). Other institutions are also involved in community outreach but usually as integral part of community engagement (Bovaird, 2000).

However, at University of Pretoria (UP), Community development is integrated into teaching and learning within the existing faculties. The University perceives community engagement as "an institution of higher learning." The University of Pretoria through its nine faculties and student voluntary organizations are positioned to use its skills and knowledge base to empower and assist communities in their development ventures.

The UP sees Community Engagement as a "key priority, entrenched in their strategic objectives and in their vision and mission statements. The UP further strives to be responsive to the changing South African environment in all spheres of society, the SADC region, the African continent and the global community" (UP, 2012). Being an integral part of teaching and learning, the support of the staff and students are enlisted in order to drive development agenda needed by identified communities. Hence community engagement is "treated as an integral part of teaching, learning and research; voluntary work done by students and institutional responsibilities. The focus is particularly on areas where the University has proven competencies that can enhance development and capacity building in identified communities" (UP, 2012).

Furthermore, at UP, there is also a department of Community Engagement which is tasked with the responsibility of using the competencies within the university to enhance development and capacity needed in identified communities (UP, 2012).

\section{The Importance of Research and Knowledge Production}

It is important to interrogate why researchers embark on research activities. Sometimes, it could be for various reasons best known to the researcher. However, when it comes to knowledge production, the reason should always be to produce knowledge that will be useful to the society and humanity (Gibbons, 1994). Anything contrary to this will be a wasteful venture. Francis Bacon quoted in Strand et al (2003:1) indicated that "...I would address one general admonition to all; that they consider what are the true ends of knowledge, and that they seek it not either for pleasure of the mind, or for contention, or for superiority to others, or for profits, or for fame, or for power, or any of these inferior things; but for the benefit and use of life."

Therefore, the true ends of knowledge is to link knowledge with social inquiry rather than leaving it disconnected from action, isolated and mired in academic culture (Strand et al, 2003:2). Strand's argument is also relevant till date considering how neighbourhoods, townships and locations around most of the universities campuses struggle with greater socio- economic and infrastructural challenges. "University resources could help to address urban decay, environmental threats, growing economic inequality and the unmet needs of vulnerable children, families, and communities in areas such as education, health care, housing, criminal and juvenile justice and employment"(Strand et al, 2003:2).

There is now a growing demand for universities and higher institutions to be responsive to local conditions, problems and needs (Gumport, 2000). These are the reasons why universities are established. They are to provide something useful to the society and particularly the communities that surround them and beyond (Maurrasse, 2001). To this end, the work of researchers and professors need to be responsive to the public good and make meaningful impacts (Gay, 2010).

At all times, it is important to keep pursuing scholarships in researches that produces new knowledge (Gibbons, 1994), however, other forms of scholarships are equally important and need to be pursued in order to deliver improved quality of life to the community and people (Boyer, 1990). Such scholarships include scholarship of integration, of application, and of pedagogy (Strand et al, 2003: 2). Strand et al, (2003) puts it like this "scholarship of application is best suited to address society's problems in order to solve the ills that confront society."

To make this happen and realisable, university students are expected to play a vital role during and after their training at the university since they have been equipped with the necessary knowledge and skills that will make them contribute usefully and meaningfully wherever they find themselves (Kerr, 2001). At the university, the culture of citizenship education should be inculcated by involving the students in volunteering and service learning (Macfarlane, 2006). In so doing, Community Based Research (CBR) that seeks to integrate students, faculty and community members who collaboratively engage in research with the purpose of solving a pressing community problem or effecting social change will be enhanced (Strand et al, 2003). The meaning of community in this context includes but not limited to 
educational institutions, health facilities and centres, schools, infrastructure and recreational centres and so on (Strand et al, 2003).

The significance of CBR is to volunteer and work for the promotion of social economic justice and emancipation through sensitisation and education (Smith-Tolken, 2010). It is a form of university providing its skills to serve a larger community and positively impact humanity (Smith-Tolken, 2010).

\section{The Essence of Collaboration and Partnership}

Various scholars from different disciplines have described collaboration and partnership in research from different perspectives, sometimes narrowed to their areas of interests (Dillenbourg, 1999). However, there seems to be a description that cuts across the boundaries in academic discourse and generally acceptable and it goes thus "it is developed through perpetual discussion between experienced researchers and experienced community ....advocators and activities, and consequently tends to reflect issues, concerns or pressing problems as perceived by members of the community being researched, that is carried out by a heterogeneous research team; and leads to recognition not only for the researchers but also for the community-based agency that sponsors it, as well as a transfer of research skills to minority researchers, while contributing to the intervention, public education, social development, advocacy and/or empowerment goals" (Singer, 1993:19).

\section{Linking Climate Change Projects to Community Developments and Needs}

The need to ensure that the projects that will be embarked on meet the needs of communities is now increasingly recognised especially when Higher Institutions are involved in developing and implementing those projects as part of the community development venture (Richard et al, 2007). With regard to climate change mitigation and adaptation research projects, this will entail linking climate change research and the projects to the developmental needs of the community (Huq et al, 2006).

The unpredictable nature of the weather is now a major concern to various communities who rely on indigenous knowledge to forecast and predict the weather in order to engage in developmental and productive activities (ZumaNetshiukhwi et al, 2013). This method of weather prediction which has served the communities relatively well in past years is now unreliable due to climatic changes. Linking climate change and development is now of paramount importance in order to reduce people's vulnerability (Stringer et al, 2009) as climate change is impacting the poor communities and affecting them seriously thereby depriving them of meeting their developmental objectives. As a result of this, they need all supports that will capacitate them to mitigate and adapt to the bizarre weather events (Suzuki, 2011). This is the reason why community based projects undertaken by the university as part of the community service should be consistent with development priorities of the communities for them to be useful and meaningful (Altman, 1995). Though not a tertiary institution, Official Development Assistance (ODA) approach to delivering long-term sustainability projects to the various communities are very helpful. Their key ways of doing this is to assess "the risk of climate change to the ODA project and its deliverables (such as water supply, infrastructure, food security, human health, natural resources management and protection against natural hazards); The vulnerability to climate change of the community or ecosystem that is intended to benefit from the ODA project; The possible effects of the ODA project and its deliverables on the vulnerability of communities or ecosystems to climate change" (Richard et al, 2007:24-25).

Richard et al, (2007:25) indicate that "the link between adaptation and development is particularly relevant when seeking to enhance the capacity of people and communities to adapt to climate change. This adaptive capacity is often limited by a lack of resources, poor institutions and inadequate infrastructure, amongst other factors...vulnerability to climate change can therefore be reduced not only by mitigation of greenhouse gas emissions and by adaptation to the impacts of climate change, but also by development aimed at improving the living conditions and access to resources for those experiencing the impacts, as this will enhance adaptive capacity."

The view expressed above captures speaks directly to the significance of embarking on projects that will be of immense value to the community in order to alleviate the plight of climate change and its impact on the community. It also show how they can sustain the resilience through capacity building (Adger, 2013).

\section{Success Stories of FHIT'S Community Engagement Driven Projects}

The principles of community engagement outline the essential needs of research projects to be conducted for the purpose of benefiting the community (Strand et al, 2003). This is in line with the thinking of the contemporary research 
community that accentuates that research done should be able to contribute positively by impacting the society and humanity. This position is supported by Hoagwood et al (2010) when they assert that "the principles of evidence-based practices are understood as scientifically derived knowledge about specific interventions associated with specific improvements in delivery of services to the people." Community engagement is a partnership and also a beneficial collaboration that will enhance the standard of living of the community and confirm the findings of scientific research output (Ansar, 2005). Usually, it is characterise as a win-win-situation. While the community will benefits from the research output through application and demonstration, the researcher also benefits immensely because the validity of the work is confirmed through demonstration and application that is seen to be impacting the community and solving problem. This can be taken to another level by introducing the findings to other communities. Government and private sector may buy into it hence creating intellectual property in favour of the researcher and the institution. At the long run, due to economic of scale, it may be produced in a large scale and translated to huge financial gains and success if widely accepted as sustainable affordable innovation. Talking about the gains, Hoagwood et al (2010) describe this by asserting that "our hope is that by focusing a critical lens on these newer participatory paradigms, we can detect the contours of more meaningful dialectical exchanges among research community partners." The researcher will also benefit from the engagement because the collaboration will enhance the validity and usefulness of the scientific findings when demonstrated and used in the community (Patricia et al, 2008).

With regard to doctoral study for an example, it will take a minimum of 3 years for the candidate to generate and produce new knowledge from the study. Thereafter, to apply the output and findings to the needy community, it might also take a while because the findings have to be applied and demonstrated and if this work out successfully, the community will benefit accordingly. In South Africa, it is now part of the educational policy of the government and most of the universities to diffuse research findings by applying and demonstrate them to solve problems in the communities (Kraak, 2000). In so doing, the parties that are involved will have to disseminate, adopt, and adapt the new knowledge to the community in order to alleviate identified problem. Therefore, partnership and collaboration with academic researchers are now the crux of efforts to develop and deliver the types of social economic goods and services such as infrastructure, sustainable electricity, education, enterprises and so on to the needy communities in order to contribute to improving and raising the quality of life and standard of living of the people (Dominelli, 2007). However, the alliance and collaboration success hugely depend on all the parties playing their roles effectively and efficiently in order to ensure delivery as planned (Archer and Cameron, 2009). To this end, this is well articulated and exemplified in the proposal written by Meyer, 2008 to Eskom to fund the "Development of Excellence in Renewable Energy."

Against the backdrop of this, FHIT has taken some remarkable steps by not only embarking on just any research works but those that meet the needs of the communities in order to alleviate their plights and poverty. Therefore, telling the success stories, some of the communities driven and performing research projects are presented:

Fort Hare Institute of Technology (FHIT-Centre of Excellence) at the University of Fort Hare, Alice, in the rural Eastern Cape of South Africa is committed to promoting and implementing community agenda policy and various initiatives of the University of Fort Hare to communities surrounding the university. FHIT has, through numerous research works conducted and being conducted by Masters and Doctoral students and positively apply the findings and results to the needy communities in the areas of providing sustainable renewable energy and energy efficient solutions. Some of these projects are as a result of collaboration between the University, the community and the financiers.

It is pertinent to mention that most of the people living in Alice are poor who cannot afford the luxury of paying for modern electricity. This notwithstanding, FHIT projects are assisting the rural dwellers to have access to modern energy through renewable energy. FHIT has successfully, through collaboration with Tuskegee University in the USA and the Blue Crane Route designed and constructed passive solar energy efficient housing structures in three towns in the rural Eastern Cape. "A passive house is defined as a house which heats and cools itself in a purely passive way by utilizing the sun path in winter and summer respectively." FHIT has also collaborated with Eskom to construct and put to operation the first commercial size biomass gasifier plant at a sawmill in Melani village close to the University of Fort Hare (Mamphweli and Meyer 2009). The biomass gasifer is now a major source of income generation for the community and also making modern electricity available to the community through the use of sustainable energy. According to Mamphweli and Meyer (2009) "the local community has been plagued with air pollution caused by the burning of waste in a furnace for years. This project aimed at significantly reducing the pollution by using waste material as a fuel for biomass gasification to generate electricity. The waste from the commercial biomass gasifier from the sawmill is used as fuel to generate electricity. The gasifier has an electricity generation capacity of more than 1 million $\mathrm{kWh}$ per annum from a fuel which would have otherwise been a waste product" (Mamphweli and Meyer 2009).

They explain further that "the exhaust gases of the biomass gasifier are much cleaner as the gas engine uses the energy content of the producer gases $(\mathrm{CO}, \mathrm{CO} 2, \mathrm{CH} 4, \mathrm{H} 2$, etc.). The generated electricity is then used to power two 
community driven agri-businesses. Revenue generated through this can in turn be used by the community for the community's wellbeing" (Mamphweli and Meyer 2009).

These engagements showcase how FHIT is making tremendous contributions to the upliftment and improvement in the quality of life of the people in the communities. By implication, FHIT is also implementing government policies which seek to make modern electricity available to the rural remote communities through the provision of solar system projects and services. As a result of this, the sustainable energy sources and electricity are now serving as alternatives to the use of illuminating paraffin, candles and diesel for lighting for domestic usage.

\section{Critique of Collaboration and Community Engagement}

Even though remarkable successes have been achieved and reported with regard to community collaboration, engagement and outreach, some pitfalls and challenges have been identified. Challenges are multidimensional; it might be as a result of failure of providing better and further assistance to projects due to lack of maintenance thereby interrupting continuity. There could also be opposing views to the project within the community thereby stalling progress. This is why community engagement sceptics expressed their unsupportive view and concluded that "research in community based... is like mixing oil and water." However, from all indications and from the success stories above and elsewhere, community engagement is having huge impact in the lives of the people in the communities especially those in the rural remote areas (Ramirez, 2005). In view of the overwhelming benefits to the communities and the researchers during the course of engagement and thereafter, it is important to intensify efforts on how to continue with community engagement rather than put a stop to it (Marks and Jones, 2004). This will entail making the results and services rendered by the universities continually relevant to the needs of the communities. Community engagement is a viable venture and all tertiary institutions are enjoined to be involved in order to find solutions to the problems posed by global climate change and other environmental problems (Lehner, 2008).

\section{Conclusion}

It is imperative that university should continue to serve as a medium of socio-economic change and emancipation by involving surrounding communities in their research projects in order to provide the necessary skills that will help to improve quality of life. Research and knowledge production become meaningful when they impact the people in the communities and alleviate their plights and sufferings. Students should stand up to the challenge and become more responsible citizens through volunteering on community engagement activities and outreaches.

\section{Recommendations}

The essence of research is not just to produce a work, store it on a shelf and allow it to be gathering dust; there should be managers for research outputs to look for possibility by which the community could benefit from the research. It is imperative that research works that will impact on the community should be given the necessary support within the university and the support of all interested parties and stake holders should be enlisted in to achieve successful outputs.

\section{References}

Ackerman LW H 2004. Legal Nature of the South African Constitutional Revolution. From http://heinonline.org/HOL/LandingPage?handle =hein.journals/newzIndlr2004\&div=40\&id=\&page=. (Retrieved March 2, 2014).

Adger WN 2013. Building resilience to promote sustainability. From ihdp.unu.edu. (Retrieved March 16, 2014).

Altman D G 1995. Sustaining interventions in community systems: On the relationship between researchers and communities. American Journal of Public Health, 98(1): 22-27.

Archer D, Cameron A 2009. Collaborative leadership: How to succeed in an interconnected world, Butterworth-Heinemann, Oxford, UK.

Bovaird T 2007. Beyond Engagement and Participation: User and Community Coproduction of Public Services, Public Administration Review, 67(5): 846-860.

Boyer EL 1990. Scholarship reconsidered: Priorities of the professoriate, ERIC Publishers, New Jersey, USA.

Bruning ST, McGrew S, Cooper M 2006. Town-gown relationships: Exploring university-community engagement from the perspective of community members, Public Relations Review, 32(2):125-130.

Cross M, Mungadi R, Rouhani S 2002. From Policy to Practice: Curriculum reform in South African education, Comparative Education, $38(2): 171-187$. 
Dillenbourg P. 1999. What do you mean by collaborative learning? In P. Dillenbourg (Ed), Collaborative-learning: Cognitive and Computational Approaches. Oxford: Elsevier.

Dominelli L 2007. Revitalising communities in a globalising world, Ashgate Publishing Company, Burlington. USA.

Eckert P, Henschel P 2000. Supporting community involvement in the digital age- Civic responsibility and higher education. The American council on Education and The Oryx Press, CT, USA.

Education, From http://supportservices.ufs.ac.za/dl/userfiles/Documents/00001/678_eng.pdf. (Retrieved February 4, 2014).

El Ansari W 2005. Collaborative research partnerships with disadvantaged communities: challenges and potential solutions, Public Health, 119(9):758-770.

Epstein JL 1996. Perspectives and previews on research and policy for school, family, and community partnerships. Digital Printing, New York, USA.

Fourie F 2006. Towards a South African scholarship of engagement: core and supplementary tasks of a university? In pursuit of a South African scholarship of engagement, Paper presented at the CHE-HEQC/JET-CHESP Conference on Community Engagement in Higher Education 3 to 5 September 2006.

Gay G 2010. Culturally responsive teaching: Theory, research, and practice, Teachers College Press, New York, USA.

Gibbons M, Limoges C, Nowotny H, Schwartzman S 1994. The new production of knowledge: The dynamics of science and research in contemporary societies, Corporate Social Responsibility, CSR, Sustainability, Ethics \& Governance, pp 235-264.

Gibbons M, Limoges C, Nowotny H, Schwartzman S 1994. The new production of knowledge: The dynamics of science and research in contemporary societies, SAGE Publications Ltd, London, UK.

Gumport PJ 2000. Academic restructuring: Organizational change and institutional imperatives, Higher Education, 39(1):67-91.

Hall M 2010. Community Engagement in South African higher education. From http://ahero.uwc.ac.za/index.php?module=cshe\&action =viewtitle\&id=cshe_834. (Retrieved December 4, 2013).

Hoagwood KE, Jensen PS, McKay M, Olin S 2010. Redefining the boundaries; Community Engagement-Research Partnerships to Improve Children's Mental Health, Oxford University Press, New York, USA.

Huq S, Reid H, Murray LA 2006. Climate Change and Development Links. From http://hdl.handle.net/10019.1/5162. (Retrieved February 17, 2014).

Ibidunni OS 2013. Corporate Social Responsibility in Higher Education Institutions in the Development of Communities and Society in Nigeria. Corporate Social Responsibility CSR, Sustainability, Ethics \& Governance, pp 235-264.

Ilorah R 2006. The dilemma of the HBUs in South Africa, South African Journal of Higher Education, 20(3): 79-96.

Kerr C 2001. The uses of the university. From http://books.google.com. (Retrieved March 6, 2014).

Klein RJT, Eriksen SHE, Næss LO, Hammill A, Tanner TM, Robledo C, OBrien KL 2007. Portfolio screening to support the mainstreaming of adaptation to climate change into development assistance, Climatic Change, (2007) 84:23-44.

Kraak K 2000. Changing modes: New knowledge production and its implications for higher education in South Africa, Human Sciences Research Council, Pretoria, South Africa.

Lange G 2012. Developing a University-Community Engagement Conceptual Framework and Typology - a case study of a South African comprehensive university, Africa Insight, 42(2):94-111.

Lehner P 2008. The Greening of the Corporation, Changing Markets to Address Climate Change, Environmental Affairs Law Review, 35(3):385-396.

Livermore M, Midgley J 1998. The contribution of universities to building sustainable communities: The community university partnership, CRC Press, Florida, USA.

Macfarlane B 2006. The academic citizen: The virtue of service in university life. Routledge, New York, USA.

Maharajh R, Motala E, Scerri M 2011. South Africa: Reforming Higher Education and Transforming the National System of Innovation Universities in TransitionInsight and Innovation in International Development, 193-218

Mamphweli S, Meyer E 2009. Implementation of the biomass gasification project for community empowerment at Melani Village, Eastern Cape, South Africa. Renewable Energy, 34: 2923-2927.

Marks HM, Jones SR 2004. Community Service in the Transition: Shifts and Continuities in Participation from High School to College, The Journal of Higher Education, 75(3): 307-339.

Maurrasse DJ 2001. Beyond the campus: How colleges and universities form partnerships with their communities, Routledge, New York, USA.

Meaney M 2010. Redefining the Boundaries: Community-Research Partnerships to Improve Children's Mental Health. From imd.inder.cu. (Retrieved February 27, 2014).

Muthayan S 2005. Globalization, Democratization and Knowledge Production at Three South African Universities. Form http://circle.ubc.ca. (Retrieved February 7, 2014).

Netshandama VD 2010. Community development as an approach to community engagement in rural-based higher education institutions in South Africa, South African Journal of Higher Education, 24(3):342-356.

Patricia AL, Cochran EIT, Marshall CA, Garcia-Downing C, Kendall E, Cook D, , McCubbin L, Gover S, 2008. Indigenous Ways of Knowing: Implications for Participatory Research and Community. American Journal of Public Health, 98(1): 22-27.

Ramirez R, Helen A, Galin K, Donald R 2005.Community Engagement, Performance Measurement and Sustainability: Experiences from Canadian Community-Based Networks, Canadian Journal of Communication, 30(2):259-280.

Sanoff H 2000. Community participation methods in design and planning, John Wiley \& Sons Incorporation, New York, USA. 
Singer,M. (1993). Knowledge for use: Anthropology and community-centered substance abuse research. Social Science and Medicine, $37(1), 15-25$.

Smith-Tolken AR 2010. Community engagement at a higher education institution-exploring a theoretical grounding for scholarly-based service-related process. From http://ir1.sun.ac.za/handle/10019.1/5162. (Retrieved March 4, 2014).

Strand KJ, Cutforth N, Stoecker R, Marullo S 2003. Community-based research and higher education: Principles and practices, JosseyBass Publishers, Sanfracisco, California, USA.

Strand KJ, Cutforth N, Stoecker R, Marullo S 2003. Community-based research and higher education: Principles and practices, JosseyBass Publishers, Sanfracisco, California, USA.

Stringer LC, Dyer JC, Reed MS, Dougill AJ, Twyman C, Mkwambisi D 2009. Adaptations to climate change, drought and desertification: local insights to enhance policy in southern Africa, Environmental Science \& Policy, 12(7):748-765.

Suzuki R, Recoftc B, Arefin ABMS, Alrd D 2011. Community Action in a Climate Change Regime: Managing Biodiversity. From http://s3.amazonaws.com/academia.edu.documents/30281278/c9956d6015eeb1d-eeb9-4c6e-a2d4d1ef4928c531community_action_in_a_climate_change_regimelibre.pdf?awsaccesskeyid=akiaj56tqjitwsmtnpea\&expires=1393600452\&signature=gjfkkhbynxg5ai1unjjk9qc46ky\%3d. (Retrieved March 10, 2014).

UFH 2014. University of Fort Hare, Alice, South Africa. From http://ufh.ac.za/community. (Retrieved January 5, 2014).

UNISA 2008. University of South Afreica. Community Engagement and Outreach. From http://cm.unisa.ac.za/contents/departments /community/docs/CommEngagemPolicy_toManCom_26an08.pdf . (Retrieved February 11, 2014).

UP 2012. University of Pretoria. Community Engagement. From http://web.up.ac.za/default.asp?ipkCategoryID=85. (Retrieved February $28,2014)$

Waghid $Y 2002$. Knowledge production and higher education transformation in South Africa: Towards reflexivity in university teaching, research and community service, Higher Education, 43(4):457-488.

Waghid $Y$ 2002. Knowledge production and higher education transformation in South Africa: Towards reflexivity in university teaching, research and community service, Higher Education, 43(4):457-488.

Weerts DJ, Sandmann LR 2008. Building a Two-Way Street: Challenges and Opportunities for Community Engagement at Research Universities, The Review of Higher Education, 32(1):73-106.

Zuma-Netshiukhwi G, Kees Stigter, Sue Walker 2013. Use of Traditional Weather/Climate Knowledge by Farmers in the South-Western Free State of South Africa: Agrometeorological Learning by Scientists, Atmosphere 2013, 4(4), 383-410. 